\title{
The structure of Prunus avium L. crops and their importance for pollinating insects in seed orchards in Poland
}

BIOOPEN 2021 - POST-CONFERENCE ARTICLE

\section{MATEUSZ KĘSY}

Poznań University of Life Sciences, Department of Apidology, Wojska Polskiego 71C, 60-625 Poznan, Poland

E-mail: matkesy@wp.pl

\section{Abstract}

The functioning of forests in Poland is often associated with a productive role and the production of wood-based raw materials, disregarding the need to protect forest environments. In practice, the approach to the protection of nature and animals, including insects in forest areas, has changed in recent decades. Many researchers still point to the need to protect the processes taking place in forest environments. Actions are being taken to reduce monocultures in forests and to increase the biodiversity of plants and animals living among crops. A good example described in this paper is the relationship between seed plantations and insects. These relationships may have a positive effect on the fruiting process and seed production in selected tree species. This paper presents an example of the relationship between wild bees and Prunus avium L. seed plantations as an example of a positive relationship in which humans as well as pollinating insects can benefit. The structure and size of Prunus cultivation in Poland are described and the hitherto harvest of seeds is analysed. The elements of the biology of the Prunus species, important for the process of pollination of flowers by insects are also indicated. The study also indicates ways to protect bees in the forest environment.

KEYWORDS: seed production, forest crops, tree yielding, plant cultivation

\section{Introduction}

Anthropogenic activities can alter forest environments (Grodzki 2020). A way to counteract this process is to create a forest seed base of various types of trees, conifers and deciduous trees, from which seeds are obtained for further sowing and for the formation of forests (Kocięcki 1965; Fonder 2006; Matras and Fonder 2006). Many authors have pointed to the need for a more multifunctional and sustainable use of forest resources and the rich diversity of species living in forest areas (Fonder 1992; Matras 1992; Matras 2000; Chałupka et al. 2011; Szyp-Borowska et al. 2012). The overarching goals 
include the need to protect nature and maintain a seed base, allowing for forest districts to meet self-sufficiency in terms of the production of tree seedlings (Matras and Fonder 2006; Kowalczyk et al. 2011). Contemporary silviculture focuses primarily on maintaining the high diversity of native species of forest trees (Chałupka et al. 2011; Kowalczyk et al. 2011). Crops provide, above all, high-quality seed material with known genetic characteristics, which helps to protect the genetic resources of trees (Kowalczyk et al. 2011). There are many examples of the need to protect nature in an interdisciplinary manner, but a good illustration of this concept is the relationship between pollinating insects and trees that produce nectar and bee pollen, resulting in the formation of fully developed seeds capable of germination (Baddeley and Watson 2005; Cetinbas and Koyunuu 2006; Szczygieł and Wojda 2008; Chałupka et al. 2011, Kowalczyk et al. 2011). This process should be supported by active protection of bees in forest areas by introducing various species of trees, shrubs and herbaceous plants to forest monocultures, which will be able to provide food to pollinating insects throughout the year, not only in spring or summer (Kowalczyk et al. 2011). It is a necessary element that influences the reproduction of insects and their existence in forest areas and beyond (Wilkaniec and Wyrwa 1994; Frączek et al. 2020; Grodzki 2020).

\section{Prunus avium $\mathrm{L}$. in forestry}

Forest seed plantations, especially trees that produce nectar and pollen consumed by animals, are a good example of a food base for pollinating insects and bees. An example of a cultivated plant is Prunus avium L. (bird cherry), which blooms profusely in April-May and produces nectar and pollen that is valuable for bees (IBG
2021). There are eight such plantations in Poland, comprising 34.78 ha (Table 1). Although their formation has only taken place in the last two decades, they already provide seeds with valuable features in the process of silviculture. So far, the sum of seeds collected from all these plantations has amounted to $991.14 \mathrm{~kg}$, which averages to $28.50 \mathrm{~kg} / \mathrm{ha}$ (Table 1). These data comes of Krajowy Rejestr Leśnego Materiału Podstawowego in Baza Nasiennictwa Leśnego. Currently, it is the base of crops where there are problems with keeping trees in optimal health conditions, which contributes to their fruiting (Ballistreri et al. 2013). However, the maintenance of plants and breeding of various strains of these trees is a response to the needs of foresters in the field of forest seed production and the need to use $P$. avium seeds in the process of creating new forest stands, which should not contain a single species (monoculture), but rather constitute a collection of different tree species, providing animals with shelter, food and space to live. The yield of this species depends on the weather conditions during its flowering, which occurs in April and May, and the health condition of the trees. Bird cherry grows wild in Europe, Western Siberia and Central Asia. In Poland, it is found in deciduous and mixed forests. It is a light-requiring species with high soil requirements, preferring dry areas. Trees generally begin to yield at the age of 6-8 years. Abundant fruiting is usually observed at the age of 15 years. The most common form of harvesting ripe fruit is hand picking. The indicators to assess maturity are colour and consistency. Mechanical shakers are also used in seed plantations. Table 1 provides basic information on the structure of $P$. avium crops in Poland, together with an indication of their seed productivity. 
Table 1. The basic characteristics of Prunus avium L. seed orchards in Poland based on KRLMP (BNL 2019)

\begin{tabular}{|l|l|c|c|c|c|}
\hline $\begin{array}{c}\text { Regional forest } \\
\text { district }\end{array}$ & \multicolumn{1}{|c|}{$\begin{array}{c}\text { Forest } \\
\text { district }\end{array}$} & $\begin{array}{c}\text { Area } \\
\text { (ha) }\end{array}$ & $\begin{array}{c}\text { Year } \\
\text { established }\end{array}$ & $\begin{array}{c}\text { Total seed harvest } \\
\text { until 2020 (kg) }\end{array}$ & $\begin{array}{c}\text { Average seed } \\
\text { harvest (kg) }\end{array}$ \\
\hline Krosno & Dynów & 5.33 & 2005 & 70.00 & 35.00 \\
\hline Gdańsk & Elbląg & 4.20 & 2015 & 113.65 & 28.41 \\
\hline Katowice & Kędzierzyn & 5.20 & 2009 & 19.10 & 9.55 \\
\hline Lublin & Krasnystaw & 6.51 & 2009 & 0 & 0 \\
\hline Poznań & Lopuchówko & 2.18 & 2007 & 0 & 0 \\
\hline Katowice & $\begin{array}{l}\text { Rudy } \\
\text { Raciborskie }\end{array}$ & 2.39 & 2008 & 144.39 & 48.13 \\
\hline Lublin & Świdnik & 4.99 & 2003 & 575.00 & 95.83 \\
\hline Szczecinek & Świerczyna & 3.98 & 2010 & 69.00 & 34.50 \\
\hline
\end{tabular}

The importance of forest seed crops and forest vegetation for pollinating insects

The vast majority of forest areas are coniferous species with low nutritional value for pollinating insects, including Apis mellifera $\mathrm{L}$. honey bees and various species of wild bees (Frączek et al. 2020). In the area of forest seed plantations in Poland, conifers (e.g. Pinus sylvestris L., Picea abies L., Larix Mill.) and deciduous species (e.g. Tilia cordata Mill., Quercus spp., Prunus avium L.), whose main task is the production of seeds for the further creation of forest stands of known, primarily genetic origin (Chałupka et al. 2011; Kowalczyk et al. 2011). Their role, however, can be perceived much more broadly, as some of them are a crucial source of food, providing pollinating insects mainly with bee pollen and sometimes nectar (Czekońska 2020b; Frączek et al. 2020). These crops can also be made available to beekeepers - especially forest seed orchards of $T$. cordata - and they are very valuable to honeybees and other pollinating insects (Czekońska 2020a). Their flowering provides nectar as well as pollen, from which linden honey can be produced (Czekońska 2020b). Other valuable crops for bees are oak plantations, from which bee pollen can be obtained by insects (Frączek et al.
2020). Another species is $P$. avium, which also provides valuable food products for bees, here also mainly bee pollen (IBG 2021). In addition, forest areas around seed plantations may include in the forest composition species of trees and shrubs that are valuable for bees and pollinating insects, including: Padus avium, Sorbus aucuparia, Acer pseudoplatanus, Acer campestre, Acer platanoides, Tilia platyphyllos, Cerasus avium, Salix spp., Frangula alnus, Berberis vulgaris, Viburnum opulus, Corylus avellana, Ribes nigrum, Prunus spinosa, Crataegus spp. and others (Frączek et al. 2020).

\section{Protection of pollinating insects in forest areas}

When thinking about the protection of insects, one should distinguish between active and passive activities. To increase the population of pollinating insects - and above all, bee species - care should be taken to increase the number of nectar- and pollen-bearing species that are components of forests (Frączek et al. 2020). This necessity results from the low abundance of tree and shrub species in forest environments that provide food for insects in the long term (Szwagrzyk et al. 2020), which is necessary for the proper existence and reproduction of some species that also live in agricultural 
and fruit-growing environments (Wilkaniec and Wyrwa 1994). Forest environments are constantly changing due to human activity, a factor that may limit the development of animals, including invertebrates and insects (Grodzki 2020). The technological processes of tillage have changed significantly. Moreover, various plant-protection products have been used and the number of weeds present in the crop structure has been reduced (Grodzki 2020; Szwagrzyk et al. 2020). The need to protect insects in forests has been discussed in more detail so far in Instrukcja Ochrony Lasu (IOL 2012), where it is clearly stated that it is necessary to increase the biodiversity of plant species found in forest areas to increase the biodiversity of pollinating insects.

\section{Conclusions}

Increasing the biodiversity of pollinating insects, especially wild bees living in the forest structure, seems to be crucial to preserve the species diversity of these animals as well as to increase the yield of selected tree and shrub species grown in forest seed orchards. An example of such interdependence in a forest environment is the relationship between $P$. avium plantations and the bees from which seeds are produced, which are the basis for new plants. Many more examples of such connections can be found, especially for trees such as $T$. cordata, Quercus petraea Liebl. and other species for which the presence of bees and their work is essential in the fruiting of trees. Oak species are also highly wind pollinated and yet are additionally favoured by the work of bees. It can be clearly concluded that the natural environment needs to balance economic goals and animal protection, which may result in more positive changes, which will also benefit humans.

\section{References}

Baddeley, J.A., Watson, C.A. 2005. Influences of root diameter, tree age, soil depth and season on fine root survivorship in Prunus avium. Plant and Soil, 276: 15-22.

Ballistreri, G., Continella, A., Gentile, A., Amenta, M., Fabroni, S., Rapisarda, P. 2013. Fruit quality and bioactive compounds relevant to human health of sweet cherry (Prunus avium L.) cultivars grown in Italy. Food Chemistry, 140: 630-638.

Cetinbas, M., Koyunuu, F. 2006. Improving germination of Prunus avium L. seeds by gibberellic acid, potassium nitrate and thiourea. Horticultural Science (Prague), 33(3): 119 -123 .

Chałupka, W., Matras, J., Barzdajn, W., Błonkowski, S., Burczyk, J., Fonder, W., Grądzki, T., Gryzło, Z., Kacprzak, P., Kowalczyk, J., Kozioł, C., Pytko, T., Rzońca, Z., Sabor, J., Szeląg, Z., Tarasiuk, S. 2011. Program zachowania leśnych zasobów genowych i hodowli selekcyjnej drzew w Polsce na lata 2011-2035. Dyrekcja Generalna Lasów Państwowych, Warszawa.

Czekońska, K. 2020a. Zasady udostępniania obszarów leśnych właścicielom rodzin pszczelich. In: Czekońska, K., Szabla, K. (eds.), Ochrona owadów zapylających w ekosystemach leśnych, pp. 183-187. Wydawnictwo Uniwersytetu Rolniczego w Krakowie, Kraków.

Czekońska, K. 2020b. Pokarm pszczół i jego wykorzystanie. In: Czekońska K., Szabla K. (eds.), Ochrona owadów zapylających w ekosystemach leśnych, pp. 147-162. Wydawnictwo Uniwersytetu Rolniczego w Krakowie, Kraków.

Fonder, W. 1992. Program selekcji drzew i jego realizacja w Lasach Państwowych. Postępy Techniki w Leśnictwie, 51: 28-36.

Fonder, W. 2006. Realizacja Programu zachowania leśnych zasobów genowych i hodowli selekcyjnej drzew leśnych w Polsce na lata 19912010. In: Sabor, J. (ed.), Elementy genetyki i hodowli selekcyjnej drzew leśnych, pp. 537558. CILP, Warszawa.

Frączek, M., Szwagrzyk, J., Bodziarrzyk, J. 2020. Gatunki drzew, krzewów i roślin zielnych do nasadzeń lub wysiewu w różnych siedliskowych typach lasu. In: Czekońska, K., Szabla, K. (eds.), Ochrona owadów zapylających w ekosystemach leśnych, pp. 86-113. Wydawnictwo Uniwersytetu Rolniczego w Krakowie, Kraków.

Goncalves, B., Silva, A.P., Moutinho-Pereira, J., Bacelar, E., Rosa, E., Meyer, A.S. 2007. Effect of ripeness and postharvest storage on the 
evolution of colour and anthyocyanins in chervies (Prunus avium L.). Food Chemistry, 103: 976-984.

Grodzki, W. 2020. Chroniąc lasy, chronimy owady zapylające dziko żyjące. In: Czekońska, K., Szabla, K. (eds.), Ochrona owadów zapylających w ekosystemach leśnych, pp. 21-37. Wydawnictwo Uniwersytetu Rolniczego w Krakowie, Kraków.

Instrukcja Ochrony Lasu 2012. Wydawnictwo II. Centrum Informacyjne Lasów Państwowych, Warszawa, 23-119.

Jabłoński, T., Tarwacki, G., Jaworski, T. 2017. Szkodniki liściożerne drzew liściastych In: Krótkoterminowa prognoza występowania ważniejszych szkodników i chorób infekcyjnych drzew leśnych w Polsce w 2017 roku. IBL, pp. 84-89.

Kocięcki, S. 1965. Plantacje nasienne ze szczepów - zakładanie i prowadzenie. Sylwan, 109(1): 51-63.

Kocięcki, S. 1988. Wytyczne w sprawie selekcji drzew na potrzeby nasiennictwa leśnego. Prace Instytutu Badawczego Leśnictwa. Seria B, 7: 5-61.

Kowalczyk, J., Markiewicz, P., Chałupka, W., Matras, J. 2011. Plantacje nasienne - rola i znaczenie w gospodarce leśnej. Las Polski, 22: $18-20$.

Matras, J. 1992. Podstawy selekcji drzew leśnych i zachowania zasobów genetycznych. Postępy Techniki w Leśnictwie, 51: 9-15.

Matras, J. 2000. Realizacja ochrony leśnych zasobów genowych i hodowli selekcyjnej drzew w Lasach Państwowych w latach 1991-1999. Prace Instytutu Badawczego Leśnictwa. Nr 903. 2000/3: 63-83.

Matras, J., Fonder, W. 2006. Założenia Programu ochrony leśnych zasobów genowych i hodowli selekcyjnej drzew leśnych w Polsce na lata 2011-2035. Postępy Techniki w Leśnictwie, 95: 7-15.

Szczygieł, K., Wojda, T. 2008. Mikrorozmnażanie czereśni ptasiej (Prunus avium L.) i jej plantacyjna uprawa we Włoszech. Leśne Prace Badawcze, 69(1): 72-75.

Szwagrzyk, J., Bodziarczyk, J., Frączek, M. 2020. Kierunki w hodowli lasu sprzyjające owadom zapylającym. In: Czekońska, K., Szabla, K. (eds.), Ochrona owadów zapylających w ekosystemach leśnych, pp. 55-74. Wydawnictwo Uniwersytetu Rolniczego w Krawowie, Kraków.

Szyp-Borowska, I., Zawadzka, A., Zajączkowski, K. 2012. Zróżnicowanie genetyczne czereśni ptasiej (Prunus avium L.) w Polsce. Sylwan, 156(7): 502-510.

Vursavus, K., Kelebek, H., Selli, S. 2006. A study on some chemical and physico-mechanic properties of three sweet cherry variaties (Prunus avium L.) in Turkey. Journal of Food Engineering, 74: 568-575.

Wilkaniec, Z., Wyrwa, F. 1994. Ocena efektywności oblotu jabłoni przez pszczołę samotniczą Osmia rufa L. (Apoidea, Megachilidae) w badaniach izolowanych. Roczniki Akademii Rolniczej w Poznaniu, 147-153. 